\title{
Modification of Growing Medium for Container Melon (Cucumismelo L.) Production Using Goat Manure and Dolomite
}

\author{
Merakati Handajaningsih $^{\# 1}$, Hasanudin ${ }^{\# 2}$, Helfi Eka Saputra ${ }^{\# 3}$, Marwanto ${ }^{\# 4}$, Ayu P. Yuningtyas* \\ ${ }^{\#}$ Department of Agricultural Plant Production, Faculty of Agriculture, University of Bengkulu, Bengkulu, 38371A, Indonesia \\ Email: ${ }^{1}$ merakati@gmail.com; ${ }^{2}$ hasan_puskom@yahoo.com; ${ }^{3}$ helfisaputra@yahoo.com; ${ }^{4}$ pak.marwanto50@gmail.com
}

*Former Student of Department of Agricultural Plant Production, Faculty of Agriculture, University of Bengkulu, Indonesia. Email: tiasphita@yahoo.com

\begin{abstract}
The growth of melon plant requires soil rich in organic matter, well drainage, and soil pH 6.0 - 7.0. The adverse conditions are found on mostly red-yellow podsolic of Ultisol. The objective of this research was to evaluate the application of goat manure and dolomite on growth and yield of melon. The research was held from June until September 2015 in Kandang Limun, Bengkulu City. Completely Randomized Design was arranged involving goat manure doses consisted of $0 \mathrm{~kg} \mathrm{polybag}^{-1}, 3 \mathrm{~kg} \mathrm{polybag}^{-1}$, and $6 \mathrm{~kg}$ polybag ${ }^{-1}$. Another factor was that the dose of dolomite consisted of $0 \mathrm{~g} \mathrm{polybag}^{-1}\left(0 \mathrm{tons} \mathrm{ha}^{-1}\right), 100 \mathrm{~g} \mathrm{polybag}^{-1}\left(2 \mathrm{tons} \mathrm{ha}^{-1}\right)$ and $200 \mathrm{~g}$ polybag ${ }^{-1}\left(4\right.$ tons $\left.\mathrm{ha}^{-1}\right)$. Treatments were replicated three times; each experimental unit consisted of 4 polybags of plants. The result of this research revealed no interaction between goat manure and dolomite in affecting the vegetative growth of plants. The interaction between goat manure and dolomite was found affecting fruit weight, fruit diameter and the thickness of the edible fruit

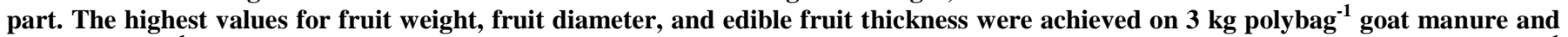
$200 \mathrm{~g}$ polybag ${ }^{-1}$ dolomite treatment, which were $725.25 \mathrm{~g}, 17.14 \mathrm{~cm}$, and $2.99 \mathrm{~cm}$ respectively. Goat manure dose of $6 \mathrm{~kg}$ polybag ${ }^{-1}$ increased stem diameter $(5.5 \mathrm{~mm})$ and fruit sweetness $\left(8.09{ }^{0} \mathrm{Brix}\right)$ compared to treatment without manure which was $5.43 \mathrm{~mm}$ and $7.31^{0}$ Brix
\end{abstract}

Keywords - melon; goat manure; dolomite; production; medium.

\section{INTRODUCTION.}

Melon is one of the favorite fruits in Indonesia which covers total production 150,347 tons in 2014 with average productivity of 18.37 ton $\mathrm{ha}^{-1}$ [1]. Meanwhile, demand for this fruit remains higher as the usage of melon also fast expanse. The fruit is not only consumed as fresh fruit but also in other food service styles such as juice, salads, and cakes. Indonesian melon farmers commonly practice two production systems, field production, and container production. Of the two systems, the field production system is more practiced than container production. Since the growing area is getting smaller, growing horticultural commodities in containers then have already been increased in numbers. Container production system offers some advantages, such as less acreage production, more efficient in usage of water and fertilizer, higher fruit or product quality, year-round production, and unlimited various media compositions. Many raw materials can be used as media in container production as long as they can meet the requirement of crops, both in soilless or soil culture.
On the other hand, usually, there is a restriction on root growth due to media volume [2]; [3] which is responsible for the decrease in yield. Physiologically, unfavorable root growth results on the decreasing photosynthetic capacity, the mechanism of which also happen when the plants are under water stress condition. The other effects of root growth restriction are the decrease in oxygen uptake and nutrient uptake from rhizosphere, disturb the compositions among cytokinin, gibberellin, and abscisic acid. These disadvantages can be eliminated when media composition and nutrients are managed properly.

Media in container production command the same essential function as the soil in field production in terms of supporting plants for nutrients. Plants in containers need the same nutrient elements and other factors as plants grown on the field to maximize plant growth and development [4]. Since roots mostly absorb nutrients and water, thus plant types, container volume, media properties, and water holding capacity must be put into considerations. Cucurbit plants such as melon develop moderate root growth, spreading $50 \mathrm{~cm}$ in nature. Porous soil structure, rich organic matter, and $\mathrm{pH} 5.5-6.0$ are the requirements for 
melon production. When this plant is intended to be grown in a container, the factors specified previously will determine the production.

Media composition used in a container production system is varied. Many melon growers prefer soil as the main growing media component. As plants need the structure of the media that meet plants' requirements, so some materials are incorporated into the soil in certain compositions. The most common simplest media material is organic matter. This is because the organic matter has a buffer function.

The soil in Bengkulu province is predominantly covered by ultisol. This type of soil is characterized by the accumulation of clay fraction in the subsurface horizon which is known as the argillic horizon. Horizon can be recognized from the clay fraction or laboratory analysis of a cross-section of the soil profile. Horizon argillic is high in Al content so sensitive to the development of plant roots. The high percentage of clay leads in reducing the power to absorb water and increasing runoff and soil erosion, an acid reaction in the soil solution, and low base saturation.

The other chemical properties of ultisol are that this soil has the potential of Al toxicity, poor organic matter content, poor soil nutrient content, especially $\mathrm{P}$ and exchangeable cations such as $\mathrm{Ca}, \mathrm{Mg}, \mathrm{Na}$, and $\mathrm{K}$, and low cation exchange capacity. Ultisol is characterized by low fertility such as low $\mathrm{pH}$, low nutrient availability, low soil organic matter, and poor drainage [5]. Modification of this type of soil into a mixture of soil and organic matter improves the media quality that suitable for plants. Once the compost mixes into the soil, some processes on biology, physic, and chemistry happen that may lead to the characteristics changes such as the rate of nitrification, biomass, and respiration of the soil, water infiltration rate, stability of soil aggregate, and water holding capacity.

Organic matter such as manures and composts play an important role in horticultural crops cultivation. The main purpose of incorporating organic matter into the soil is to improve soil fertility, while container production system, organic matter is intended as a medium mixture [6]. Goat manure has a distinctive texture because the physical structure is somewhat complicated to break that prevent the plant roots to absorb the nutrient unless decomposition is well completed. The water content of goat manure is relatively lower compared to cow manure and chicken manure. Animal manure contains nutrients that are essential for plants, the percentage of major nutrients N-P-K of goat are 1.4-0.21-2; the percentage of N-P-K of poultry are 1.50.4-0.35; while cow manure contains 0.55-0.1-0.5 percent of N-P-K [4]. Goat manure has a long period of effect on plant growth due to its gradual nutrient availability for plants.

Organic material such as goat manure does not only play an important role in helping the availability of nutrients in the soil but also help in the improvement of the physical, chemical, and biological soil. Especially for the type Ultisol which tends to have a higher clay fraction when compared to the dust and sand fractions, making the soil becomes denser and resulted in low water holding capacity, so it is necessary to add organic matter derived from goat manure.

Different compositions of media in container production, affect plant growth, and development, thus will influence end yield. Media composition was responded differently by some horticultural crops like melon [7], [8]; bell pepper [9], and okra [10]. The response showed by plant growth and development as well as yield about compost application is also much depends on the compost quality.

Dolomite, $\mathrm{CaMg}\left(\mathrm{CO}_{3}\right)_{2}$, is a fertilizer that is derived from secondary mineral deposits, consisting of magnesium and calcium. Dolomite is a soil conditioner used to improve soil $\mathrm{pH}$ of acid soils $(<6)$ to reach the neutral acidity $(\mathrm{pH}=7)-$ nearly neutral condition of soil acidity ease of nutrients in the soil absorbed by plants. Liming with dolomite may also increase potassium nutrients needed for the formation of plant cell walls. The addition of dolomite into the media can increase the availability of $\mathrm{Ca}$ and $\mathrm{Mg}$ in the soil which will trigger cell turgor and chlorophyll formation so that the process of photosynthesis increased, the product of photosynthesis is also increasing. Dolomite besides increasing $\mathrm{Ca}$, and $\mathrm{Mg}$ nutrients can also increase the availability of other nutrients and improve soil physical properties. For the field practice, dolomite must be added to the soil before planting to obtain the desired benefits.

The previous work of [7] showed that additional goat manure to Ultisol container medium did increase melon fruit weight and diameter. The media mixture in that experiment still had $\mathrm{pH} 5.0$, the condition of which had not met yet for melon growth and development. Dolomite appears to be one of the soil amendments to increase soil $\mathrm{pH}$ in containerized melon production using Ultisol and goat manure mixture.

\section{MATERIALS AND METHODS}

The experiment was carried out from June until September 2015 in Bengkulu City, $15 \mathrm{~m}$ above sea level. Complete Random Design was set for polybag experiment. Two treatments were arranged in factorial experiment consisted of doses of goat manure, they were $0 \mathrm{~kg} \mathrm{polybag}^{-1}$, $3 \mathrm{~kg}$ polybag ${ }^{-1}$, and $6 \mathrm{~kg}$ polybag ${ }^{-1}$, while doses of dolomite consisted of $0 \mathrm{~g} \mathrm{polybag}^{-1}, 100 \mathrm{~g}^{\text {polybag }}{ }^{-1}$, and $200 \mathrm{~g}$ polybag $^{-1}$. Treatments were replicated three times; six plants were planted on each experimental unit.

\section{A. Cultural Practice}

Seeds of melon var. Action 434 were selected for their visual quality and then sown in polybags $8 \mathrm{~cm} \times 12 \mathrm{~cm}$. One seed was sown $5 \mathrm{~cm}$ depth in each seedling polybag containing media soil: compost $(1: 1 \mathrm{v} / \mathrm{v})$. The polybags were arranged, the humidity of media was kept steady by hand spraying and well maintained on the nursery for three weeks. Carbofuran was incorporated into the media to prevent seedling damage from insects.

Growing media for transplanted melon was prepared seven days before the seedlings were transplanted. It consisted of topsoil and goat manure using polybag $40 \mathrm{~cm} \mathrm{x}$ $50 \mathrm{~cm}$. The soil was Ultisol with $\mathrm{pH} 4.9$, texture sandy clay, and low cation exchange capacity (13.48). The soil was mixed with goat manure and dolomite according to the treatment level - the final weight of the mixture comprised $10 \mathrm{~kg}$. Seedlings of 21 days old were transplanted into the growing polybag containers. Seedling polybag was cut on the bottom side, the melon seedling was carefully put into the growing polybag in an upright position, and seedling polybag was then pulled. This method prevented the young plant from root damage. The containers were set on open 
area $50 \mathrm{~cm}$ center to center in a row, and $75 \mathrm{~cm}$ center to center between rows.

Fertilizers and their application rates in this experiment were Urea at $8.3 \mathrm{~g} \mathrm{plant}^{-1}$, Super Phosphate (SP-36) at $7.1 \mathrm{~g}$ plant $^{-1}, \mathrm{KCl}$ at $7.1 \mathrm{~g}$ plant $^{-1}$, and compound or mixed fertilizer NPK (16:16:16) at $2.4 \mathrm{~g} \mathrm{plant}^{-1}$ per application. The Urea was basally applied on plants at 14 days after transplanting (DAT), Super Phosphate and $\mathrm{KCl}$ were banded $5 \mathrm{~cm}$ from the center of the plants when plants were transplanted. Compound fertilizer was applied according to the banding method [4] when the plants' age were 21, 28, 35, and 42 DAT.

Maintenance of plants included regular watering, replanting, pest and disease control, staking (plant training), fruit thinning, and fruit wrapping. Watering was done two times in the morning at around 6:00 a.m. to 8:00 pm and in the afternoon at around 16:00 to 18:00 pm. Replanting was done because there were seeds that did not grow normally, replanting was done one week after planting. The disease that attacks this research that crackle or late blight disease caused by fungus or downy mildew (mildew down). The control was carried out mechanically and chemically. Affected leaves were controlled mechanically by cutting or trimming; chemical control was done using the fungicide which contains active ingredient methyl Tiofanat $70 \%$ at a dose of $1 \mathrm{gL}^{-1}$. Chemically control was carried out from the age of 45-60 days after planting in every three days.

Twenty-five days after transplanting, plants were trained to make them growing vertically. The main stem of the plant was tied with a nylon thread (wrapping string), and the other end of the thread was connected to timber construction. Apical meristem was cut when the node of the main stem had already reached $21^{\text {st }}$ node. Axillary stems were removed except for the axillary stems grown from the nodes of $9-13$ of the main stem where the fruits would be selected. Selection of fruit was done, one young fruit was left on each plant until harvest time, while other young fruits were removed. Once the fruit was selected, it was covered with coarse paper to prevent insect attack. Fruits were harvested at full slip stage when the full net on the surface of the fruit skin was formed and rough, the tendril became dry, and the flavor came out. Fruits were picked by cutting the vines 2 $\mathrm{cm}$ from fruit basal.

\section{B. Data Collection}

Observations were attributed to variables of growth, yield and fruit qualities including plant height $(\mathrm{cm})$, number of leaves, stem diameter $(\mathrm{mm})$, leaf area $\left(\mathrm{cm}^{2}\right)$, fruit weight $(\mathrm{g})$, fruit diameter $(\mathrm{cm})$, edible fruit thickness $(\mathrm{cm})$ and soluble solid content ( ${ }^{0}$ Brix). Plant height was measured from the basal stem to the growing point of the main stem. Leaf numbers were addressed for full open leaves on each plant both at the main stem and branches, while leaf area was measured using Leaf Area Meter. Plant height, leaf numbers, and leaf area were taken at 30, 45, and 60 DAT. Fruit diameter was measured from end to end of exocarp after the fruit was crosscut. Soluble Solid Content (SSC) was valued using the hand-refract meter.

\section{RESULTS AND DISCUSSION}

\section{A. Effects of Doses of Goat Manure}

Stem diameter at 60 days after transplanting was the only vegetative growth variable of the plant which was responded significantly to a dose of goat manure treatment, while other growth variables, i.e. plant height, leaf area, and the number of leaves was not affected by treatments. The addition of goat manure to growing media resulted in higher stem diameter (Fig.1).

Goat manure used in this experiment contained total - $\mathrm{N}$ $0.53 \%, \mathrm{P}_{2} \mathrm{O}_{5} 0.38 \%, \mathrm{~K}_{2} \mathrm{O} 0.20 \%, \mathrm{CaO} 0.30 \%$ and $\mathrm{MgO}$ $0.15 \%$. Within $6 \mathrm{~kg}$ manure which was the highest dose, those values were equal to $31.8 \mathrm{~g} \mathrm{~N}, 22.8 \mathrm{~g} \mathrm{P}_{2} \mathrm{O}_{5}, 12 \mathrm{~g} \mathrm{~K}_{2} \mathrm{O}$, $18 \mathrm{~g} \mathrm{CaO}$, and $0.9 \mathrm{~g} \mathrm{MgO}$. The stem diameter of a plant at the application $6 \mathrm{~kg}$ of goat manure was $5.49 \mathrm{~cm}$. Manure application functions as a nutrient source for plants improves soil aggregates, increases the Cation Exchange Capacity and the number of pores in the soil, reduces soil acidity and can reduce the availability of elements that are toxic for plants such as $\mathrm{Fe}, \mathrm{Al}$, and $\mathrm{Mn}$.

The stem is planted organ having a function to distribute water, minerals, and photosynthates. The greater the stem diameter, the better the distribution of water, nutrients, and photosynthates. Nitrogen was revealed to increase stem diameter and plant height on corn [11]. Also, the composition of growing medium with the high content of nitrogen, phosphor, and potassium increased stem diameter of papaya seedlings and 11 weeks after plant establishment compared to a growing medium having low nutrient composition [12]. Nitrogen uptake was faster and higher by the plant when manure was incorporated as bio-activator into compost materials [13]. The growth of egusi melon which included vine length and the number of leaves as well as nutrient uptake increased significantly when a high dose of nitrogen was accompanied by a high dose of potassium [14]. The application of poultry manure to egusi melon proved to enhance vine diameter, vine length, and number of leaves at 30 days after transplanting [15]. Poultry manure is known to release nutrients faster than goat manure, the situation of which caused the late response on plant growth and development on this goat compost treatment.

This study reported there was no response of leaf area and leaf number to goat manure and dolomite treatment. Table 1 showed that incorporating $100 \mathrm{~g}$ of dolomite and $4 \mathrm{~kg}$ or $6 \mathrm{~kg}$ into the media resulted in higher leaf area at 45 and 60 DAT. Compared to the previous study [7], the plants in this study produced a smaller leaf area even though the leaves number were not different. The reduction in leaf growth might cause a severe dry season during the experiment.

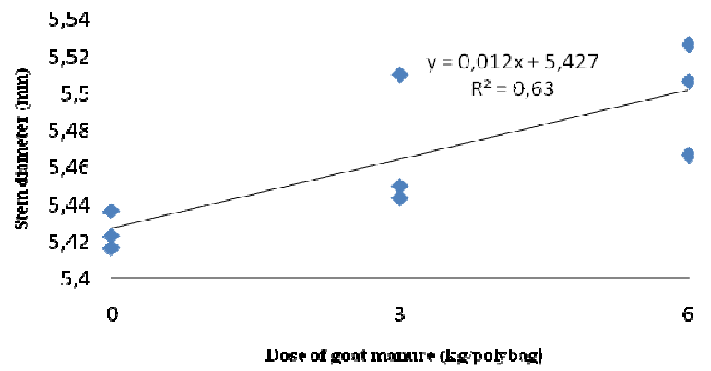

Fig. 1. Main stem diameter as influenced by a dose of goat manure 
TABLE I

LEAF AREA $\left(\mathrm{CM}^{2}\right)$ OF MELON TREATED WITH GOAT MANURE (G) AND DOLOMITE (D)

\begin{tabular}{|l|c|c|c|}
\hline \multirow{2}{*}{ Treatments } & \multicolumn{3}{|c|}{ Days After Transplanting } \\
\cline { 2 - 4 } & $\mathbf{3 0}$ & $\mathbf{4 5}$ & $\mathbf{6 0}$ \\
\hline G0D0 & 1253,03 & 2657,96 & 2354.87 \\
\hline G0D100 & 1242,04 & 2740,12 & 2422.61 \\
\hline G0D200 & 1255,62 & 2668,46 & 2317.10 \\
\hline G3D0 & 1244,69 & 2669,14 & 2354.43 \\
\hline G3D100 & 1218,84 & 2704,03 & 2424.86 \\
\hline G3D200 & 806,63 & 2633,60 & 2392.30 \\
\hline G6D0 & 1115,14 & 2526,72 & 2127.36 \\
\hline G6D100 & 1335,68 & 2719,23 & 2467.39 \\
\hline G6D200 & 1115,82 & 2527,37 & 2126.39 \\
\hline
\end{tabular}

Potassium is a major plant nutrient which is responsible in transporting water and nutrients from roots and distributing photosynthates from green parts to all plant parts through the stem. Increasing goat manure also resulted in higher soluble solid content (Fig. 2); it was maybe due to more potassium content in the media. Maximum soluble solid content value at the dose of dolomite $6 \mathrm{~kg}$ polybag ${ }^{-1}$ was $8.09^{0} \mathrm{Brix}$; this is slightly under the minimum standard required for melon quality $\left(9^{0} \mathrm{Brix}\right)$.

The linear response on SSC due to the increasing dose of goat manure incorporated into the growing media was also revealed from the previous research [7]. Another experiment carried out by [16] explained that total soluble solid increased as melon fruit developed and the maximum at 48 days after anthesis of flowers, while the total sugar reached the highest at 44 days after anthesis. At the maximum level of fruit maturity usually, it is characterized visually by full slip at the basal peduncle and the strong aroma of the fruit.

The sweetness of the edible fruit part is partly the function of potassium. Even though this element is absorbed as cation from soil solution, reference [17] proved that spraying foliar potassium during fruit development stage could increase sugar content and other quality indices of muskmelon fruit. Manures incorporated into soil develop mineralization and release nutrients by which finally the roots will absorb nutrient elements to support plant growth and development. According to [18], increasing absorption of potassium, together with calcium and magnesium, resulted in the higher content of fructose that was responsible for the fruit sweetness. References [19] and [20] mentioned that fructose, as well as glucose, are the dominant in melon fruit at the beginning and middle period of fruit development, from 0 until 40 days after pollination. Sucrose is the lowest content during those periods. As the fruit goes to further development to the maturity, the sugar content of fructose and glucose decline while sucrose increases sharply. Various melon cultivars contain a different percentage of the three types of sugar, but the pattern of sugar accumulation is similar. Even different parts of fruit show sugar compositions differently.

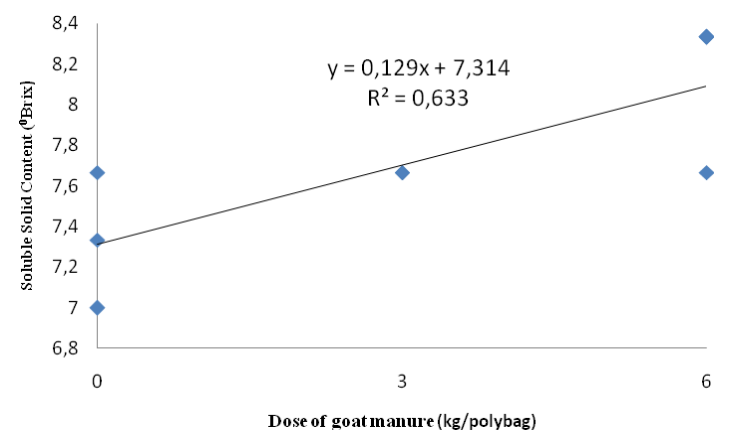

Fig. 2. The solid soluble content of fruit as influenced by the dose of goat manure.

The level of sweetness in the melon fruit is classified into four levels; they are a low group $(<8 \%)$, moderate group (8$13 \%)$, high class (13-18\%) and very high group (18\%) [18]. According to [18] an increase in the sweetness of the melon is due to the increase in uptake of $\mathrm{K}, \mathrm{Ca}$, and $\mathrm{Mg}$ in solution and easily absorbed and availability cations are still in a comparable amount. In this study, goat manure and dolomite had no significant effect on the interaction, but the goat manure singly had a significant effect.

\section{B. Effects of Doses of Goat Manure and Dolomite}

It is stated by [21] that growth is the process occurs in an organism including plants by which of certain characteristic increased size and capacity. Increasing the size of the plant determines the quality of the crop is harvested. Plant height in this experiment did not show its response to the treatment at 30 days after transplanting (Fig. 3), which was the beginning phase of actively planting growth and development. It responded differently to the application of goat manure and dolomite at 45 days after transplanting. Shorter plant height was noted on treatments of a dose of dolomite at $0,100 \mathrm{~g}$ or $200 \mathrm{~g}$ without the presence of goat manure. As the plant gets older, the role of goat manure was more prominent. Dolomite dose $200 \mathrm{~g} \mathrm{polybag}^{-1}$ amended to the soil, and goat manure created favored stem growth. The $\mathrm{pH}$ of 6.0 measured in a medium added with $200 \mathrm{~g}$ of dolomite has met the requirement for better plant growth and development. The effects of dolomite in improving plant growth and yield were noted for horticultural plant [22], food crop [23], and para rubber plants [24]. The characteristic of OM as slow release fertilizer clearly explain the late effect in plant height differences among treatments.

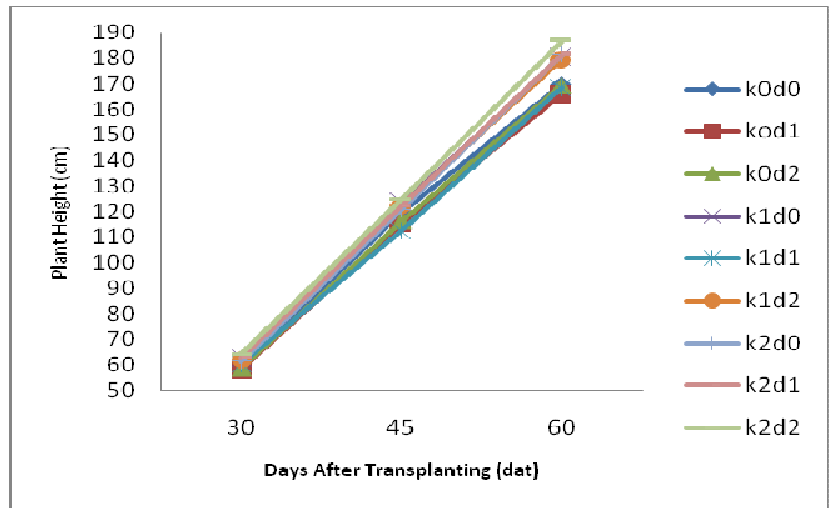

Fig. 3. Plant height at 30, 45, and 60 days after transplanting at different levels of goat manure (k) and a dose of dolomite (d) 
The amount of OM into soil determine the proportion between the two medium components. Reference [25] showed sandy soil and cattle manure with straw OM in proportion 1:1 resulted in better yield and quality of muskmelon compared to sandy soil and sheep mixtures. Similar work was completed by [26]. The interaction between goat manure and dolomite in the experiment significantly influenced fruit weight, fruit diameter, and good fruit thickness.

Fruit weight is one of the significant economic components in melon beside fruit sweetness and fleshy color. Fruit development is supported by carbohydrate. Since plant carbohydrate is a photosynthetic product, thus plant leaf area contributes to fruit development. Research on the relationship between leaves as source and fruit as a target that was done by [27] proved that number of leaves did not only contribute to fruit weight of melon but also fruit quality indices as well. It was explained that plants with undefoliation treatment reached the highest fruit weight compared to the plants with leaves defoliated. The number of leaves refers to the leaf area that can perform photosynthesis. A large amount of assimilating which is distributed toward the fruit yields higher fruit weight. Leaf area in this study tended to be higher in the treatment of dose $3 \mathrm{~kg}$ goat manure combined with dolomite lime $100 \mathrm{~kg}$ although the difference with other treatments was not significant. This increased the weight of the fruit (Figure 4.), the information of which was in line with the previous experiment by [7]. It might be that certain growth substances directed the movement of assimilating to the fruit.

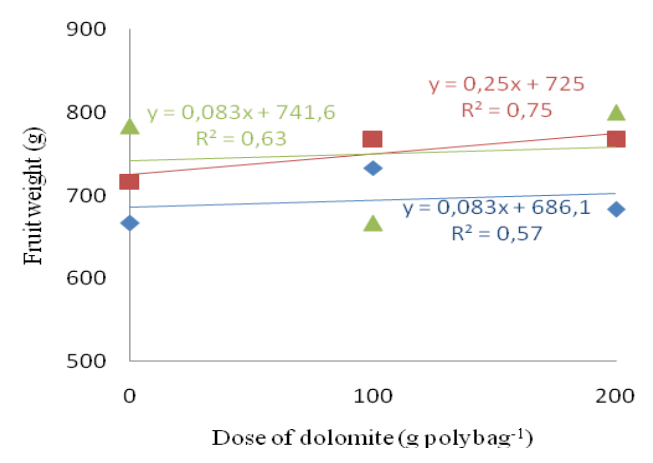

Fig. 4. The response of fruit weight to a dose of dolomite at different doses of goat manure ((blue line- $0 \mathrm{~kg}$, red line- $3 \mathrm{~kg}$, green line- $6 \mathrm{~kg}$ )

The usage $6 \mathrm{~kg}$ goat manure in this experiment gave lower effect on fruit weight when it was combined with 100 $\mathrm{g}$ to $200 \mathrm{~g}$ dolomite compared to the application of $3 \mathrm{~kg}$ goat manure with the same combination of dolomite. The addition of dolomite up to $200 \mathrm{~g}$ did not improve yield and qualities when there was no manure supplement in the medium. As explained by [28] that besides temperature and oxygen, $\mathrm{pH}$ of the medium will influence the activities of soil microbes. The presence of dolomite appeared stimulating microbial to accelerate nutrients release of manure.

The presence of manure can support soil fertility and the growth of microorganisms in the soil to improve the properties of the physical, chemical, and biological. Primary nutrients $\mathrm{N}, \mathrm{P}$, and $\mathrm{K}$ in goat manure are essential to vegetative growth and generative growth expressed in dry weight of plant parts. Nitrogen supply increased the dry weight of leaf, stem, and fruit of melon [29].

Plant dry weight is an expression of net assimilates during the growth period. An experiment conducted by [25] revealed that the mineralization of the three major nutrient elements responded differently according to ratio soil: compost, and types of compost. A high portion of compost in the media served a high amount of nutrients that were mineralized. Cattle compost released nitrogen higher than sheep compost. Element mineralization pattern was different with phosphor in which phosphor in sheep compost released faster than cattle compost in small proportion between soil and compost, while potassium of sheep compost was served in high amount. The time and the amount at which nutrient is released is significant because nutrients must be available for plants at the proper amount according to the stage of plant growth.

Dolomite application can increase the availability of $\mathrm{Ca}$, and $\mathrm{Mg}$ in the soil stimulates cell turgor and chlorophyll formation. The further effect is increasing the process of photosynthesis, and the product of photosynthesis also increase The availability of macro and micronutrients, followed by the absorption of nutrients by the plants causing such enzymes to work optimally with chlorophyll employment also increased thus making the fruit weight, fruit diameter, and thick fruit pulp can be increased. Research conducted by [18], demonstrated the use of organic materials, potassium, and dolomite at doses 30 ton/ha, potassium $175 \mathrm{~kg} / \mathrm{ha}$ and $150 \mathrm{~kg} \mathrm{Ca} \mathrm{Mg} / \mathrm{ha}$ ) capable of producing the highest fruit weight $(2.42 \mathrm{~kg} / \mathrm{tan})$ and the thickness of edible fruit $(3.56 \mathrm{~cm})$.

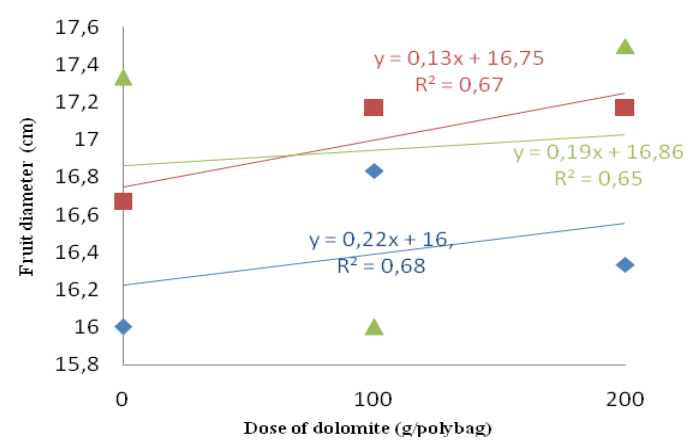

Fig. 5. The response of fruit diameter to a dose of dolomite at different doses of goat manure (blue line- $0 \mathrm{~kg}$, red line- $3 \mathrm{~kg}$, green line- $6 \mathrm{~kg}$ )

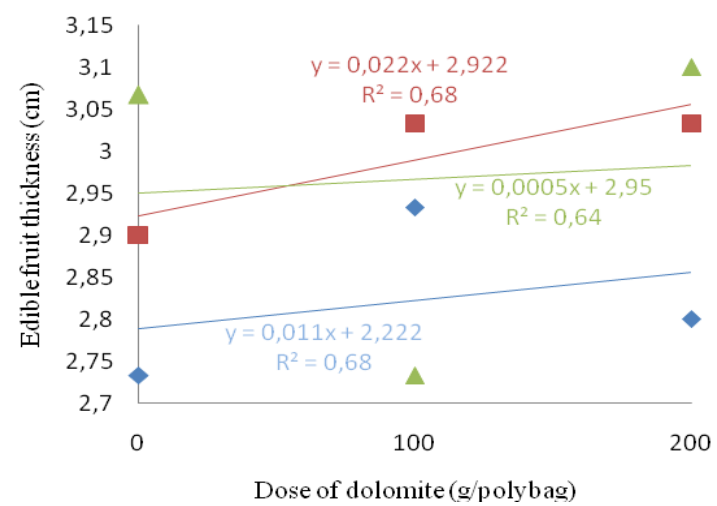

Fig. 6. The response of edible fruit thickness to a dose of dolomite at different doses of goat manure ((blue line- $0 \mathrm{~kg}$, red line- $3 \mathrm{~kg}$, green line- 6 $\mathrm{kg})$ 
Figure 5 showed fruit diameter response to doses of goat manure and dolomite was similar to fruit weight. The plants grown on ultisol without the addition of goat manure produced the smallest fruit diameter even though lime was amended into the media. Adding goat manure into the ultisol significantly increased the diameter of fruit. Research involving the application of manure clearly explain that elements existing in manure were including tracing elements, the components that were very important in accelerating the movement process to enlarge the diameter as well as the thickness of the edible part of the fruit.

As mentioned by [30] the process of fruit development is divided into fruit set and fruit growth. The phase of fruit growth consists of cell division and is followed by cell expansion. Those processes determine the fruit size which can be measured on fruit diameter and fruit weight. Also, the presence of trace elements such as zinc and manganese in manure might play important role to support fruit weight and quality of pomegranate. Foliar spraying of the two microelements significantly improved fruit yield per tree, total soluble solid content, and ratio aril: peel of pomegranate [31]. Zinc is known to be an essential part of some enzymatic processes and protein as well as carbohydrate metabolism. Manganese is another trace element which is involved in many enzymatic reactions in cells and plant membranes. Reference [32] showed that concentrations of total soluble solids, sucrose, $\mathrm{K}$ content, and volatile acetate components significantly increased in fruit flesh, which should improve the taste and aroma of melon. Fruit changes in chemical characteristics are closely related to the fruit ripening [33].

\section{CONCLUSIONS}

This experiment demonstrated that medium composition for container melon production consisted of $7 \mathrm{~kg}$ soil and amended with $3 \mathrm{~kg}$ goat manure and $200 \mathrm{~g}$ dolomite polybag $^{-1}$ resulting in highest fruit weight, fruit diameter, and edible fruit thickness. Doses of goat manure up to $6 \mathrm{~kg}$ polybag $^{-1}$ increased stem diameter of plant and the solid soluble content of melon fruit. Application of dolomite into soil did not improve growth and yield as well as the quality of melon if the media was absent from manure.

\section{REFERENCES}

[1] Biro Pusat Statistik (Indonesian Statistic Bureau), Statistik Produksi Hortikultura Indonesia, Kementerian Pertanian, Direktorat Jendral Hortikultura, 2015.

[2] C. A. Bouzo, and J. C. Favaro, "Container size effect on the plant production and precocity in tomato (Solanum lycopersicum L)," Bulgarian J. Agric. Sci, vol. 21 (2), pp 325 - 332, 2015.

[3] W. Nelson, "Container types and containerized stock for New Zealand afforestation," New Zealand J. Forestry Sci., vol. 26 (1/2), pp $184-190,1996$.

[4] H. Davidson, R. Mecklenburg, and C. Peterson, Nursery Management. Administration and Culture, $4^{\text {th }}$ ed. Rev. New Jersey, Prentice Hall, 2000.

[5] Badan Penelitian dan Pengembangan Pertanian, Peta arahan tata ruang pertanian Provinsi Bengkulu, Departemen Pertanian, Jakarta, 2006.

[6] M. Raviv, "Production of high-quality composts for horticultural purposes: A Mini review," HortTechnology, vol. 15 (1), pp. 52-57, Jan - March 2005.

[7] R. Pasaribu, "Respon pertumbuhan, hasil dan kualitas tanaman melon (Cucumis melo L.) terhadap dosis pupuk kandang kambing dan dosis pupuk anorganik", Bachelor thesis, University of Bengkulu, 2014.
[8] A. Radhouani, M. El Bekkay, and A. Ferchichi, "Effect of substrate on vegetative growth, quantitative and qualitative production of muskmelon (Cucumis melo) conducted in soilless culture", African J. of Agric. Res.,. vol. 6 (3), pp. 578-585, 2011.

[9] M.A.O. Llaven, J. L. G. Jimenez, B. I. C. Coro, R. Rincon-Rosales, J. M. Molina, L. Dendooven, and F. A. Gutierrez-Miceli, "Fruit characteristics of Bell Pepper cultivated in sheep manure vermicompost substituted soil," J. Plant Nutr., vol 31, pp. 1585 1598, 2008.

[10] A. B. Gulshan, H. M.Saeed, S. Javid, T. Meryem, M. I. Atta, and M. Amin-ud-din, "Effects of animal manure on the growth and development of okra (Abelmoschus esculentus L.)," J. Agric. Biol. Sci., vol. 8 (3), pp.213 - 218, 2013.

[11] H. A. Eltelib, M. A. Hamad, and E. E. Ali, "The effect of nitrogen and phosphorus fertilization on growth, yield, and quality of forage maize (Zea mays L.)," J. of Agron., vol. 5 (3), pp 515 - 518, 2006.

[12] R.D. Utami, W.D. Widodo, and K. Suketi, "Respon pertumbuhan bibit pepaya pada delapan jenis komposisi media tanam," in Proc. Seminar Ilmiah Perhorti, Vol. I: Tanaman Buah, 2013, p. 80 - 88.

[13] Y. Sondang, K. Anty, and R. Alfina,"The influence of bioactivator cattle feces against the length of composting and $\mathrm{C} / \mathrm{N}$ ratio from three kinds of organic material,” Intl. J. Of Adv. Sci. Eng. Inf. Tech, vol.5 (2), pp. $74-77,2014$.

[14] J. O. Olaniyi and B.A. Tella, "Effects of nitrogen and potassium fertilizers on the growth, seed yield and nutritional values of egusi melon (Citrullus lanatus (Thumb) Manf.) in Ogbomoso South West Nigeria," Intl. Res. J. Of Plant Sci., vol. 2(11), pp. 328 - 331, 2011.

[15] O. A. Agba, I.B. Adinya, E.A. Agbogo, M.A. Oniah, N. Tiku, Abam, Prince, and M. Lifu, "Responses of egusi melon (Colocynthis citrollus L.) to poultry manure in Obubra, Cross River, South-South Nigeria," Continental J. Agron., vol. 3, pp. 13-18, 2009.

[16] A. A. Abu-Goukh, A.F.M. Baraka, and M.M.A. Elballa, "Physicochemical changes during growth and development of 'Galia' cantaloupes. II. Chemical changes," Agric. Biol. J. N. Am., vol. 2(6), pp. 952-963, 2011.

[17] G.E. Lester, J. L. Jifon, and G. Roger, "Supplemental foliar potassium applications during muskmelon fruit development can improve fruit quality, ascorbic acid, and beta-carotene contents," J. Amer. Soc. Hort. Sci., vol. 130 (2), pp. 649-653, 2005.

[18] Siswanto, B.Wisnu, and Purwadi, "Karakteristik lahan untuk tanaman melon (Cucumis melo L.) dalam kaitannya dengan peningkatan kadar gula," J. Pertanian Mapeta, vol. 12(2), 125 - 131, 2010.

[19] P.A. de Souza, A. do Nascimento Simoes, M. Puiatti, J. G. Junior, and M. R. da Silva Vieira, "Carbohydrate metabolism and quality of fruits from the Cucumis genus," Acad. J. Agric. Res. , vol. 1 (7), pp. $101-105,2013$.

[20] T. Barzegar, M. Delshad, A. K. Kashi, C. Mauve, and J. Ghashghaie, "Sugar accumulation pattern and contents in developing fruits of two Iranian melon cultivars," Iranian J. of Plant Phisiol., vol. 5 (3), pp. $1353-1359,2015$

[21] S.M. Sitompul and B. Guritno, Analisis Pertumbuhan Tanaman, Gadjah Mada University Press, Yogyakarta, 1995.

[22] S. Hikam and P. B. Timotiwu, "Roles of calcium and magnesium as selection factors in Sweetcorn quality improvement on acidic redyellow podsolic soil," AGRIVITA, vol. 38 (2), pp. 163 - 173, 2016.

[23] Sukristiyonubowo, I. A. Sipahutar, T. Vadari, and A. Sofyan, "Management of inherent soil fertility of newly opened wetland rice field for sustainable rice farming in Indonesia," J. Plant Breeding and Crop Sci.,, vol. 3 (8), pp. 146 - 153, 2011.

[24] I. Damrongrak, J. Onthong, and C. Nilnond, "Effect of fertilizer and dolomite applications on growth and yield of tapping rubber trees," Songklanakarin J.Sci. Technol., vol. 37(6), pp. 643 - 650, Nov - Dec, 2015 .

[25] L. Jianming, W. Pute, M. H. Behboudian, W. Zhonghong, Z Zhirong, and A. Morton, "Responses of muskmelon to cattle or sheep manure compost mixed with sandy soil," J. Organic Systems, vol. 3 (2), pp. $40-50,2008$.

[26] D.J. Amara, and S. M. Mourad, "Influence of organic manure on the vegetative growth and tuber production of potato (Solanum tuberosum L. var Spunta) in a Sahara desert region," Intl .J.Agric. and CropSci., vol. 5(22),pp. 2724 - 2731, 2013.

[27] H. Nerson, "Source-sink relationships and their effects on fruit growth and quality in Casaba Melon (Cucumis melo L. var. Inodorus)," Fruit, Vegetable and Cereal Science and Biotechnology, vol. 3 (1), pp. $44-47,2009$. 
[28] K. T. Morgan, K. E. Cushman, and S. Sato, "Release mechanism for slow- and controlled release fertilizers and strategies for their use in vegetable production," HortTechnology, vol. 19 (1), Jan - March, pp $10-12,2009$.

[29] M.T. Castellanos, M.J. Cabello, M.del C. Cartagena, A.M. Tarquis, A. Arce, and F. Ribas, "Growth dynamics and yield of melon as influenced by nitrogen fertilizer," Sci. Agric. (piracicaba, Braz.), vol. 68(2), pp. 191- 199, 2011.

[30] K.Higashi, K. Hosoya, H. Ezura, "Histological analysis of fruit development between two melon (Cucumis melo L. reticulatus) genotypes setting a different size of fruit," J. Exp. Bot., vol. 50 (339), pp.1593-1597, 1999.
[31] M. Hasani, Z. Zamani, G. Sayaghebi, and R. Fatahi, "Effects of zinc and manganese as foliar spray on pomegranate yield, fruit quality and leaf minerals," J. Soil Plant Nutr., vol. 12(3), pp. 471 - 480, 2012.

[32] M. Tang, H. Zhao, Z. Bie , Q. Li ${ }^{1}$, J. Xie ${ }^{2}$, X. Shi , H. Yi, and Y. Sun, "Effect of different potassium levels on growth and quality in two melon cultivars and two growing-seasons," J. Food, Agric. \& Environment, vol.10 (2), pp 570-575, 2012.

[33] S. V. Menon, and T.V. Ramana Rao, "Nutritional quality of muskmelon fruit as revealed by its biochemical properties during different rates of ripening," Intl. Food Res. J., vol. 19(4), pp. 1621 $1628,2012$. 